\begin{abstract}
Ahmad-Zaluki NA, Campbell K \& Goodacre A (2011) Earnings management in Malaysian IPOs: the East Asian crisis, ownership control and post-IPO performance, International Journal of Accounting, 46 (2), pp. 111-137.
\end{abstract}

This is the peer reviewed version of this article

NOTICE: this is the author's version of a work that was accepted for publication in International Journal of Accounting. Changes resulting from the publishing process, such as peer review, editing, corrections, structural formatting, and other quality control mechanisms may not be reflected in this document. Changes may have been made to this work since it was submitted for publication. A definitive version was subsequently published in International Journal of Accounting, [VOL 46, ISS 2 (2011)] DOI:

http://dx.doi.org/10.1016/j.intacc.2011.04.001 


\title{
Earnings management in Malaysian IPOs: the East Asian crisis, ownership control and post-IPO performance
}

\author{
Nurwati A. Ahmad-Zaluki \\ (Universiti Utara Malaysia, Malaysia) \\ Kevin Campbell \\ (University of Stirling, Scotland, UK) \\ Alan Goodacre * \\ (University of Stirling, Scotland, UK) \\ This version: 11 September 2010
}

\begin{abstract}
We find evidence of income-increasing earnings management in Malaysian IPOs, which occurs primarily for IPOs during a period of severe economic stress (the East Asian crisis). Within the high ownership concentration Malaysian market, post-IPO control concerns also appear to constrain IPO earnings management: owners seem willing to accept reduced IPO proceeds and signaling opportunities to increase the likelihood of retaining control of the company post-IPO. The requirement to provide a profit guarantee does not seem to greatly affect earnings management. IPO companies engaging in aggressive income-increasing earnings management have significantly worse market-based performance than their more conservative counterparts, but again only for IPOs issued during the economic crisis period. Overall, the results suggest that personal liquidity concerns are an important factor in IPO decisions during the economic crisis.
\end{abstract}

JEL classification: G32

Keywords: initial public offerings, earnings management, ownership structure, long run stock market performance

*Corresponding author:

Alan Goodacre

Accounting and Finance Division

Stirling Management School

University of Stirling

Stirling FK9 4LA

Scotland, UK

Tel: +44 (0)1786 467291

Fax: +44 (0)1786 467308

e-mail: alan.goodacre@stir.ac.uk

Nurwati A. Ahmad-Zaluki is Senior Lecturer at the Universiti Utara Malaysia and formerly Research Fellow at the University of Stirling, Kevin Campbell is Senior Lecturer in Finance at the University of Stirling and Alan Goodacre is Professor of Accounting and Finance at the University of Stirling. We appreciate the very helpful, constructive comments from Rashad Abdel-Khalik (the editor) and the two anonymous referees who have contributed significantly in helping improve the structure of the paper and the arguments therein. We have also benefited from the comments of Chris Veld, participants at the EAA Annual Conference at University College Dublin and the BAA Annual Conference at Royal Holloway, University of London. The financial support of the Malaysian government (JPA) and the Universiti Utara Malaysia is gratefully acknowledged (for Nurwati A. Ahmad-Zaluki). We thank the Public Information Centre, Kuala Lumpur Stock Exchange (Bursa Malaysia) for the usage of the library and Brahim Saadouni from the University of Manchester for the provision of his PACAP database and his collection of Malaysian prospectuses. The usual disclaimer applies. 


\title{
Earnings management in Malaysian IPOs: the East Asian crisis, ownership control and post-IPO performance
}

\begin{abstract}
We find evidence of income-increasing earnings management in Malaysian IPOs, which occurs primarily for IPOs during a period of severe economic stress (the East Asian crisis). Within the high ownership concentration Malaysian market, post-IPO control concerns also appear to constrain IPO earnings management: owners seem willing to accept reduced IPO proceeds and signaling opportunities to increase the likelihood of retaining control of the company post-IPO. The requirement to provide a profit guarantee does not seem to greatly affect earnings management. IPO companies engaging in aggressive incomeincreasing earnings management have significantly worse market-based performance than their more conservative counterparts, but again only for IPOs issued during the economic crisis period. Overall, the results suggest that personal liquidity concerns are an important factor in IPO decisions during the economic crisis.
\end{abstract}

JEL classification: G32

Keywords: initial public offerings, earnings management, ownership structure, long run stock market performance 


\section{Earnings management in Malaysian IPOs: the East Asian crisis, ownership control and post-IPO performance}

\section{Introduction}

Most prior studies of earnings management in the context of IPOs (e.g., Teoh et al., 1998a; DuCharme et al., 2001, 2004; Roosenboom et al., 2003; Chen et al., 2005) suggest that companies opportunistically manage their earnings upwards through income-increasing accruals to increase offering proceeds. ${ }^{1}$ These studies also typically find that issuers with unusually high accruals in the IPO year experience poor post-IPO stock returns. More recently, Ball and Shivakumar (2008) question the 'hypothesis of widespread and substantial earnings management by IPO firms', arguing that enhanced scrutiny by market monitors and regulators likely reduces managers' incentives to engage in such activity.

While a small number of prior studies investigate cross-sectional variation seeking to assess the determinants of IPO earnings management propensity in different contexts (e.g., Aharony et al., 1993; Neill et al., 1995; Zhou \& Elder, 2002; Chen et al., 2005; Nagata \& Hachiya, 2006; Cormier \& Martinez, 2006), these mainly use data from developed markets. The present study investigates the pervasiveness of earnings management across IPOs and the specific factors which affect decisions to manage earnings, within the context of a developing market, Malaysia. The Malaysian environment is particularly interesting as it has several distinctive features which may affect managerial incentives to manage earnings within the IPO context. First, there is a high level of ownership concentration (often involving family ownership) in Malaysia, and higher levels of post-IPO involvement can reduce shortterm incentives. Second, prospectus earnings forecasts are mandatory, which may discourage managers from unrealistic optimism, especially when coupled with the requirement for some

\footnotetext{
${ }^{1}$ Exceptions include Aharony et al. (1993) who find no evidence of income-increasing pre-IPO discretionary accruals. Also, Kimbro (2005) finds that managers respond differently to the managerial agency issues in the distinctive institutional environment in China; they engage in income-reducing earnings management prior to Ashare IPOs in China to reduce the initial IPO offer price and/or to shift profits to future years.
} 
companies during the study period to provide profit guarantees. Third, the period encompassed by the analysis includes the East Asian crisis, a period of significant economic stress which reduced profitability and confidence. These features increase the difficulty of taking a company to market. However, if a successful IPO is necessary to address liquidity issues for a company (or its owners), IPO deferral may not be an easy option. Fourth, Malaysia provides a rich environment to assess the relative impacts of owners' short-term wealth gain/loss from the IPO, signaling, and post-IPO control concerns while controlling for other potential determinants of earnings management (auditor reputation, underwriter prestige, company age, initial returns, leverage and company size). Finally, it provides an opportunity to investigate the relationship between earnings management and post-IPO market-based performance heretofore unexplored.

Using a sample of 250 IPOs over the period 1990-2000, the results provide evidence of IPO year income-increasing earnings management, but this occurs primarily during the period of economic stress. The requirement to provide a profit guarantee does not appear to greatly affect earnings management. Within the high ownership concentration market of Malaysia, concerns about post-IPO control appear to constrain IPO earnings management. That is, owners apparently accept reduced IPO proceeds to increase their likelihood of retaining post-IPO control of the company. We speculate that this may reflect decisions to use an IPO to maintain owners' personal consumption during the difficult economic climate of the Asian crisis period. Older companies and those audited by a prestigious audit firm exhibit lower levels of earnings management, consistent with notions of reduced information asymmetry and/or reduced opportunities for managers to manipulate earnings. While IPO companies engaging in aggressive (income-increasing) earnings management experience worse post-IPO marketbased performance than their more conservative counterparts (in line with prior research), this occurs only for IPOs issued during the economic crisis period.

The remainder of the paper proceeds as follows. Section 2 provides a brief description of the Malaysian institutional context for the study, followed by hypothesis development in Section 3. Section 4 outlines the research methods and Section 5 describes sample selection and data. Section 6 reports the results of the empirical study and Section 7 concludes. 


\section{Institutional context}

The context for the study, Malaysia, provides a useful environment to study the impact of a period of economic stress and of other factors on the level of IPO earnings management. In contrast with other developing countries, Leuz et al. (2003) identify the Malaysian equity market as of high importance relative to population size (of a similar level to the UK and US). They also argue that the equity market has high ownership concentration coupled with relatively high levels of earnings management. IPOs are a significant source of finance in Malaysia, with a total of RM49.9 billion (about $£ 6.8$ billion or US\$13.1 billion) raised through IPOs over the period from 1973 to 2004 (Bank Negara Malaysia, 2005); this accounts for $36 \%$ of all capital raised from the equity market and $11 \%$ of total funds raised over the period. The economic crisis in East Asia in 1997 and 1998 profoundly affected Malaysia: real GDP grew by 8.7\% per annum from 1990 to 1996, but then declined by 7.4\% in 1998, before recovering to achieve growth of $5.6 \%$ in 1999 . Consequently, the equity market crashed, declining by 52\% during 1997 leading to a major fall in funds raised through equity issues during 1998. Similarly, most companies suffered a decline in profitability. Overall, the total earnings after tax of listed non-financial companies declined by RM3 billion and RM14 billion in 1997 and 1998, respectively (Saleh \& Ahmed, 2005). This period of economic stress created a major challenge for managers and advisers seeking to maintain investors’ confidence in IPO companies’ performance. Indeed, prior research documents that stressful conditions such as the East Asian crisis potentially affect management's accounting choice behavior (e.g., Smith et al., 2001; Saleh \& Ahmed, 2005). Similarly, the impact of an earlier economic crisis (the 1990 Persian Gulf Crisis) on earnings management propensity was highlighted by Han and Wang (1998). Incentives to manage earnings to compensate for poor operating performance and reduced confidence about future earnings can be greater during crisis periods.

Unlike many other countries, Malaysian IPOs are required to provide within the prospectus an earnings forecast for the next financial year. Ironically, at the same time as the economic crisis, many companies were affected by the additional requirement to provide a three-year profit guarantee, a unique feature of the Malaysian regulatory environment. This regulation commits founders to achieve 
$90 \%$ of the profits forecast in the prospectus and $90 \%$ of the forecast profits for the two years following official listing. Before November 1994, founders of all companies were subject to threeyear share moratorium (lock-up period) regulations, requiring them to hold at least $45 \%$ of the issued paid-up shares of the company for one year after the company's admission to the Kuala Lumpur Stock Exchange; thereafter they could dispose of 15\% of the shares per annum. Between November 1994 and July 1997, companies had to choose between the three-year share moratorium period and a profit guarantee in the form of either the deposit of KLSE-listed shares with an independent third party or a bank guarantee. This requirement applied to companies listed on the Main Board that were involved in construction and services (e.g., Finance, Hotels, Properties, and Trading sectors) or specialized activities (e.g., Mining, Plantation and Trusts sectors) and to all companies listed on the Second Board. The profit guarantee requirement was finally withdrawn in April 1999 due to 'widespread noncompliance' and difficulties with enforcement, exacerbated by the East Asian economic crisis (WanHussin \& Ripain, 2003). Even so, the requirement was in place for part of the sample period so provides an opportunity to investigate its impact on a company's earnings management propensity. The three-year share moratorium remains (in slightly revised form), so founders have incentives to support a high stock price following an IPO (perhaps through earnings management) if they intend to sell their holdings following the lock-up period (Teoh et al., 1998a).

\section{Hypothesis development}

\subsection{IPO earnings management in general}

In general, research in non-IPO settings suggests that earnings management occurs in situations of increased scrutiny such as inter alia government agency investigations (Jones, 1991), price controls (Lim \& Matolcsy, 1999) and company distress (Saleh \& Ahmed, 2005; Ahmed et al., 2008). The direction of earnings management typically depends upon managers' incentives. For example, income-reducing earnings management is observed in price control regimes (Lim \& Matolcsy, 1999), when managers potentially benefit from subsequent price increases, and during debt renegotiation, hoping to benefit from government support or improved borrowing terms during the Asian financial crisis (Saleh \& Ahmed, 2005). Jaggi and Lee (2002), based on US data, find that the 
direction of earnings management is determined by the extent of financial distress and the outcomes of debt renegotiations. In contrast to these incentives for income-reducing accruals, poor earnings performance may encourage managers to preserve their reputations via income-increasing earnings management activity.

While initial public offerings can also increase stakeholder scrutiny, they provide additional and different managerial incentives for earnings management, as there can be considerable information asymmetry between owners and potential new investors. High reported earnings prior to and/or at the time of the IPO can lead to a higher offer price and a commensurate increase in owners' wealth in the short-term. This wealth-increasing incentive can encourage owners/managers to engage in 'opportunistic' income-increasing earnings management (e.g., Teoh et al., 1998a; DuCharme et al., 2001, 2004; Roosenboom et al., 2003; Chen et al., 2005). On the other hand, the increased stakeholder scrutiny and monitoring by auditors and others may cause income-increasing earnings management to be less prevalent than prior research suggests (Ball \& Shivakumar, 2008).

By contrast, signaling models suggest that owners of high quality companies signal quality by underpricing IPO shares. Owners retain a large equity stake and benefit subsequently by selling further shares at a higher price in the aftermarket (e.g., Spiess \& Pettway, 1997; Espenlaub \& Tonks, 1998). Managers have incentives to use income-reducing accruals in this context, though stringent Malaysian share moratorium (lock-up period) regulations discourage such behavior.

Two prior studies examine earnings management in Malaysian IPOs. Abdul Rahman and Wan Abdullah (2005) find significant positive discretionary current accruals (DCA) in the IPO year, reporting a high mean (median) DCA \% of lagged assets of 68.6\% (4.9\%); this mean/median disparity suggests possible outlier issues. They do not find evidence of a significant relationship between DCAs in the IPO year and post-IPO stock returns. Wan-Hussin and Ripain (2003) examine the income smoothing behavior of IPO companies that provide profit guarantees and find no relationship between income smoothing and ex-post guarantee surplus or shortfall. Unfortunately, the paper suffers from some limitations due to the application of the model. We extend this prior work by seeking to disentangle the environmental features that affect earnings management in Malaysian IPOs. 
Overall, the competing managerial incentives in the IPO context, particularly within the Malaysian environment, make it difficult to predict a priori the incidence and/or direction of earnings management. Thus, the first hypothesis considers whether there is any general evidence of earnings management in the IPO year, testable as (in alternative form):

H1: Malaysian IPO companies exhibit non-zero earnings management in the IPO year.

In Malaysia, companies can list on either the Main or the Second Board of the Kuala Lumpur Stock Exchange (KLSE), renamed Bursa Malaysia from 1 May 2004. Information asymmetry is likely lower for Main Board companies as the Main Board requires greater paid-up capital, a longer trading history and more detailed prospectus information. Main Board issues are also typically (though not always) larger than those listed on the Second Board. Thus, Second Board IPO companies may be able to retain private information more successfully than larger companies, suggesting a greater potential to engage in earnings management. This issue is addressed first to identify whether further analysis needs to be undertaken on separate samples based on the board of listing.

At least three features of the Malaysian environment potentially impact on the propensity and direction of IPO earnings management: the Asian crisis; the requirement for some companies to offer profit guarantees; and, owners' desire to maintain control of their company in a context of high levels of family control and closely-held ownership structure. Hypotheses relating to these three are developed in the following sections.

\subsection{Economic conditions}

As indicated above, the sample period encompasses the East Asian crisis years 1997-1998, a period of considerable economic uncertainty. During the crisis, managers undertook income-reducing earnings management during debt renegotiation in Malaysia, perhaps hoping to benefit from government support or improved borrowing terms (Saleh \& Ahmed, 2005). Alternatively, managers may have recognized that the market tolerates poor performance during an external shock (crisis) environment, so may have depressed earnings further, via accruals, to enable greater post-shock performance improvements to the benefit of managers' reputation (a big-bath argument). Ahmed et al. 
(2008) find that higher equity values are associated with such distress-related income-reducing accruals, suggesting that the market appreciates managers' attempts to transfer wealth to shareholders or perhaps their adoption of a big-bath approach. On the other hand, it is likely that any distressinduced income-reducing earnings management activity may be dampened by the increased monitoring of companies' performance by auditors at such a time (Chia et al., 2007). Given the nature of managerial incentives and the potential timing flexibility of an IPO, the crisis itself is less likely to provide incentives for income-reducing earnings management in IPOs. Rather, the Asian crisis may have encouraged IPO managers to increase reported earnings via earnings management to maintain their reputation, to enable an IPO to proceed in a difficult financial environment or, for some companies, to achieve a profit guarantee. This reasoning suggests two related hypotheses:

H2: Malaysian IPO companies exhibit income-increasing earnings management during the 1997-1998 period of economic crisis.

H2a: Malaysian IPO companies exhibit a higher level of income-increasing earnings management during the 1997-1998 period of economic crisis than during the non-crisis period.

\subsection{Profit guarantees}

For part of the sample period (1995-1998) some Main Board and most Second Board IPOs were required to provide profit guarantees (see Section 2 above). Companies with IPO profit guarantees have conflicting incentives. Managers are likely to seek to achieve the target profit to maintain reputation, initially suggesting the potential for income-increasing earnings management. On the other hand, the extent and the direction of earnings management depend on earnings management behavior prior to the IPO year since accruals tend to reverse in the subsequent years. Further, the IPO profit target may be ambitious or conservative depending on economic and company specific characteristics. The requirement to provide a profit guarantee may itself encourage managers to be more conservative in setting the earnings target; it may also inspire tighter audit or regulatory oversight. In addition, managers of IPO companies which comfortably meet an earnings target may create income-reducing discretionary accruals to reduce earnings-forecast deviation (as found by 
Cormier \& Martinez, 2006) or perhaps to create a reserve that can be used to achieve future earnings targets. If the penalty for failure to meet (future) profit guarantees is substantial, then attempts to decrease current over-target earnings might be expected. However, the potential for such incometransferring behavior is likely to be largely constrained during the crisis period by companies' generally poor profitability, when income-increasing needs may pervade. These countervailing arguments lead to the third hypothesis.

H3: Earnings management by Malaysian companies that guarantee profit differs from earnings management by companies that do not offer guarantees.

\subsection{Retained ownership}

A standard argument in the IPO literature is that existing owners generally seek a high initial offer price (subject to satisfactory share take-up) in order to maximize offer proceeds and their (shortterm) wealth. Thus, IPO companies in which insiders sell a larger proportion of their ownership interest (lower ownership retention) are more likely to engage in income-increasing earnings management. These wealth protection arguments suggest a negative relationship between earnings management and the proportion of shares retained (RETOWN). As outlined above, signaling models also suggest a negative relationship. Other research argues that the larger the proportion of shares issued to new investors, the greater the likely accuracy of profit forecasts (Chen et al., 2001). This reflects a greater need for outsiders to rely on the IPO prospectus for information, as well as a greater potential payout if forecasts are not met. This suggests a reduced incentive to manage earnings when the existing owners retain a larger post-IPO proportion of the company (Cormier \& Martinez, 2006), which again implies a negative relationship between earnings management and retained ownership. ${ }^{2}$

By contrast, concerns about retaining post-IPO control suggest a potential positive relationship between earnings management and retained ownership. While control retention is generally an important issue in IPO decisions (Brau \& Fawcett, 2006; Alavi et al., 2008), it is particularly likely

\footnotetext{
${ }^{2}$ Interestingly, both Cormier and Martinez (2006) and Chen et al. (2001) find a positive relationship in their empirical investigations, which is inconsistent with this expectation; i.e., higher ownership retention companies tend to adopt income-increasing earnings management.
} 
that, in a closely-held ownership environment such as Malaysia, pre-IPO owners are concerned about the potential loss of control following the partial transfer of ownership (Nagata \& Hachiya, 2006). One way to alleviate such concerns is to allocate shares to many small investors through underpricing, thereby reducing both the threat of takeover and the monitoring by large block holders (Brennan \& Franks, 1997; Pham et al., 2003; Alavi et al., 2008). Companies in which post-IPO retained ownership is relatively low are likely to be more concerned about loss of control and outside monitoring. They are, therefore, more likely to manage earnings conservatively (zero or income-reducing DCA) to reduce the IPO offer price, ensure a high initial return and oversubscription, and enable greater share allocation to smaller investors. ${ }^{3}$ This implies a positive relationship between earnings management and retained ownership. Evidence of large scale underpricing in Malaysia (e.g., mean IPO underpricing of 99\%, reported in Jelic et al., 2001) is consistent with this argument. The high ownership concentration in Malaysia (Leuz et al., 2003) also suggests that control is important to preIPO owners. Indeed, for our sample of IPO companies over $75 \%$ of the shares on average are retained by the original owners post-IPO, and control is retained in all sample IPOs (minimum retained ownership greater than $50 \%$ of shares) (see Table 1 , later). However, this positive relationship between earnings management and retained ownership is not consistent with short-term wealth (offer proceeds) maximization. In other words, owners may be willing to sacrifice short-term wealth to ensure post-IPO control of their company.

Finally, owners may also sell for diversification and/or personal liquidity reasons. Liquidity is likely to be of particular significance during the Asian crisis period, especially consumption-based sales by owners whose wealth is concentrated in a family-controlled company. Taking the company to

\footnotetext{
${ }^{3}$ The following extract from S16.3 (Applications and Acceptances) of the prospectus of P.I.E. Industrial Berhad (p.87) provides an illustration of the typical conditions concerning oversubscription, including an indication of the intention of wide share distribution: "In the event of over-subscription, acceptance of applications will be subject to ballot to be conducted in the manner as approved by the Directors. Due consideration will be given to the desirability of distributing the Public Issue and Offer Shares to a reasonable number of applicants with a view to broadening the shareholding base of the Company and to establish an adequate market in the Shares of the Company. Acceptance of application will be made in a manner so as to comply with the Securities Commission's shareholding spread requirements that at least $25 \%$ of the issued and paid-up share capital is in the hands of public shareholders and a minimum number of 1,000 public shareholders (including up to a maximum of 250 employees) holding not less than 1,000 Shares each. Applicants will be selected in a manner to be determined by the Directors of PIB. In the event the shareholding spread is not met, the Company may not be allowed to proceed with its listing." (emphasis added by the present paper authors).
} 
market during the difficult economic environment is likely to be a challenge, and may encourage the use of income-increasing accruals to bolster profitability.

The relative importance of these competing motives (wealth protection, signaling, concern about control and personal liquidity) is an interesting issue, particularly in the high ownership concentration Malaysian environment. These potentially conflicting incentives mean that $a$ priori the directional relationship between earnings management and retained ownership (RETOWN) is uncertain. Thus, our fourth hypothesis is:

H4: Earnings management by Malaysian IPO companies is related to pre-IPO owners' level of postIPO retained ownership.

\subsection{Control variables: other factors influencing earnings management propensity}

In light of the wide variation in earnings management practices across companies, this paper also considers, as a secondary issue, the importance of other earnings management motives in the Malaysian environment. Six factors are investigated, all identified in prior literature as potentially influencing the level of earnings management.

Auditors and underwriters both play a significant role in reducing information asymmetry between company managers/owners and potential investors. Auditor reports on the reliability of the financial data included in the prospectus and the underwriter signal the quality of new issues. Aharony et al. (1993) argue that high-quality auditors and underwriters have greater incentives to provide accurate information in IPOs to avoid litigation costs and reputational damage. Thus, earnings management is more likely discovered by higher quality auditors and underwriters. However, company managers who believe that income-increasing earnings management leads to a higher IPO valuation have countervailing incentives to appoint low-quality auditors/underwriters who are less likely to detect the manipulations. Managers are likely to appoint high-quality auditors and underwriters when the signaling benefits exceed potential IPO short-term wealth loss from reduced earnings management. In prior studies, both Zhou and Elder (2002) for the US and Chen et al. (2005) for Taiwan find that IPOs audited by a large (high quality) auditor engage in less earnings 
management (lower discretionary accruals) in the IPO year. Overall, these arguments suggest that IPO companies with high-quality auditors and/or underwriters are less likely to manipulate earnings, implying a negative relationship with DCA.

It can be argued that the longer the operating history of a company, the more likely it is to be based on a sound business model and to have a lower level of information asymmetry, suggesting a reduced need and/or opportunity to engage in earnings management (Nagata \& Hachiya, 2006). Thus, a negative relationship is expected between company age and the level of earnings management.

Earnings management may also be related to IPO initial returns (underpricing). Generally, managers may use income-increasing discretionary accruals to overstate income to obtain a higher offer price, which in turn reduces the initial return. In her study of the Chinese IPO market, Kimbro (2005) also finds a negative relationship between earnings management and initial returns. She argues that, in the Chinese environment, managers have incentives to underprice to compensate for higher agency costs arising from continued state ownership, regulatory and political factors. In both situations, earnings management is expected to be negatively associated with IPO initial returns (underpricing).

Aharony et al. (1993) argue that companies with higher leverage are more likely to engage in income-increasing earnings management to ensure the successful completion of an IPO due to the pressure to repay debt. However, the counter-argument is also tenable, where managers use incomereducing accruals to lower earnings, leading to a lower offer price, higher initial return which in turn is more likely to lead to a successful IPO offer, albeit with lower proceeds. It can also be argued that closeness to debt covenants (proxied by a high debt ratio) encourages the use of income-increasing earnings management. However, a high debt ratio implies lower equity and a reduced need to manage investor perceptions via discretionary accruals (Cormier \& Martinez, 2006). These contradictory arguments suggest that a priori the expected directional relationship between earnings management and leverage is indeterminate. Prior research also suggests that the relationship may differ in a period of economic crisis (Saleh \& Ahmed, 2005; Ahmed et al., 2008). 
Finally, notwithstanding its indirect link with the board of listing, individual company size may have a separate, distinguishable impact on earnings management (Aharony et al., 1993). Larger companies tend to attract greater analyst and investor interest, with lower information asymmetry reducing the potential opportunities for earnings management. Political costs related to being publicly traded may also encourage earnings reduction activities in large companies (Jones, 1991). These arguments imply a negative relationship between earnings management and company size, as observed empirically by Aharony et al. (1993). Board of listing is also included as a control to check whether the potential lower information asymmetry in Main Board companies may discourage earnings management.

\subsection{Earnings management and post-IPO long run stock market performance}

Several empirical studies focus on the relationship between earnings management and postIPO performance (e.g., Teoh et al., 1998a; Teoh et al., 1998; DuCharme et al., 2001, 2004; Roosenboom et al., 2003; Abdul Rahman \& Wan Abdullah, 2005). Teoh et al. (1998a) provide evidence that, on average, IPO issuers increase accruals and report earnings in excess of cash flows in the IPO year. They also find that DCA predict the cross-sectional variation in post-IPO long run stock return performance. 'Aggressive’ earnings management companies, with higher income-increasing accruals in the IPO year, experience poorer stock return performance in the three years post-IPO than 'conservative' earnings management companies. They argue that investors are misled by the high earnings numbers reported at the time of IPOs and so put too high a price on the new issues. A similar negative relationship between the size of the DCA in the IPO year and stock returns over the next three years is found for both Dutch (Roosenboom et al., 2003) and Spanish IPOs (Pastor-Llorca \& Poveda-Fuentes, 2006). This negative relationship between earnings management and subsequent stock return performance is used to argue that opportunistic IPO earnings management has the potential to (at least partially) explain long term stock market return underperformance of IPOs. These observations and arguments lead to our fifth hypothesis:

H5: 'Aggressive’ (higher income-increasing earnings management) Malaysian IPO companies exhibit a poorer long run stock return performance than their more 'conservative' counterparts. 


\section{Methods}

\subsection{Measure of earnings management}

Following DuCharme et al. (2001, 2004) and Roosenboom et al. (2003), discretionary current accruals (DCA) are used to proxy for earnings management, since managers are likely to have greater discretion over short term than over long term accruals (Teoh et al., 1998a, b). Dechow et al. (1995) suggest that the 'Modified Jones' model is the most powerful model for detecting earnings management so we adopt this model here, consistent with other IPO studies (Teoh et al., 1998a; Roosenboom et al., 2003). The model separates total current accruals into expected (nondiscretionary) and abnormal (discretionary) components. The modification to the model introduced by Jones (1991) is that nondiscretionary accruals are estimated from a cross-sectional ${ }^{4}$ model in which changes in sales are also adjusted for changes in trade receivables. This reduces the possibility of credit sales manipulation resulting from the timing of revenue recognition (Dechow et al., 1995). Consistent with prior research (e.g., Teoh et al., 1998, 1998a; Cormier \& Martinez, 2006), we focus on IPO year accruals, which include both pre-IPO and post-IPO months. Two years of financial statement data are required to compute the earnings management proxy but were typically not available in the pre-IPO prospectus in sufficient detail. Consequently, the data are obtained from the first post-IPO published annual reports, thereby precluding investigation of pre-IPO earnings management.

Expected current accruals for each of the IPO sample companies in a given year are estimated using a portfolio comprising all level 3 industry peers available on Datastream. A cross-sectional regression is separately estimated in each financial year for each industry portfolio. This estimation allows parameters to vary over time and by industries. Consistent with most prior studies, industry portfolios contain at least 10 companies, with IPO companies and companies that made an IPO in the previous three years excluded. Combining small, broadly similar, industries resulted in six industry groups: (i) Basic Industries; (ii) Consumer Goods (Cyclical and Non-Cyclical); (iii) Services (Cyclical and Non-Cyclical); (iv) General Industrials and Information Technology; (v) Resources and Utilities;

\footnotetext{
${ }^{4}$ The time-series approach is infeasible for IPOs because the time-series of data is too short to allow estimation of the regression parameters (Peasnell et al., 2000).
} 
and (vi) Real Estate Development. This procedure yields 84 industry-year estimation portfolios during the period, consisting of 4,308 seasoned company-years. Industry portfolios vary in size across industries and over time, average 51 constituents and range from the required minimum of 10 constituents (in two industry years) to 191 for 'Basic Industries' in 2001. Nondiscretionary accruals for each IPO company in each year are then computed using the estimated model coefficients from each industry-year estimation portfolio. Specifically, discretionary current accruals (DCA), those subject to managerial manipulation, are calculated as the difference between total current accruals and nondiscretionary current accruals.

\subsection{Factors influencing levels of earnings management}

After describing the overall time series pattern of earnings management, univariate analysis is briefly conducted to investigate patterns of DCA in years subsequent to the IPO, and on the influence of economic conditions (specifically the East Asian crisis period) and the requirement for some IPO companies to provide a profit guarantee.

A multivariate specification is also used to investigate hypotheses 2 through 4, while controlling for additional factors that may influence earnings management. The level of IPO year earnings management is regressed on experimental variables relating to crisis years, profit guarantees and the level of retained share ownership together with several additional control variables: auditor reputation, underwriter prestige, company age, size of initial returns (underpricing), the degree of leverage, company size and board of listing. The estimated regression model is:

$$
\begin{gathered}
\text { DCAYRO }_{i}=\alpha_{0}+\beta_{1} \text { CRISIS }+\beta_{2} \text { PG }+\beta_{3} \text { RETOWN }+\beta_{4} \text { AUDITOR }+\beta_{5} U N D W R+\beta_{6} \text { AGE }+ \\
\beta_{7} I R+\beta_{8} L E V+\beta_{9} \operatorname{InMV}+\beta_{10} B O A R D+\varepsilon_{i},
\end{gathered}
$$

where:

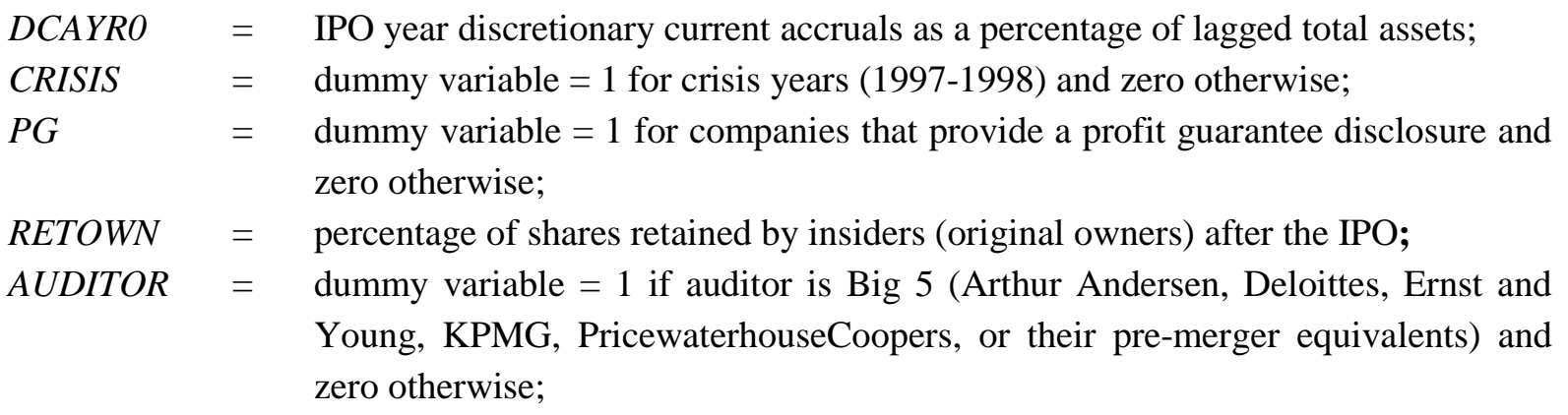




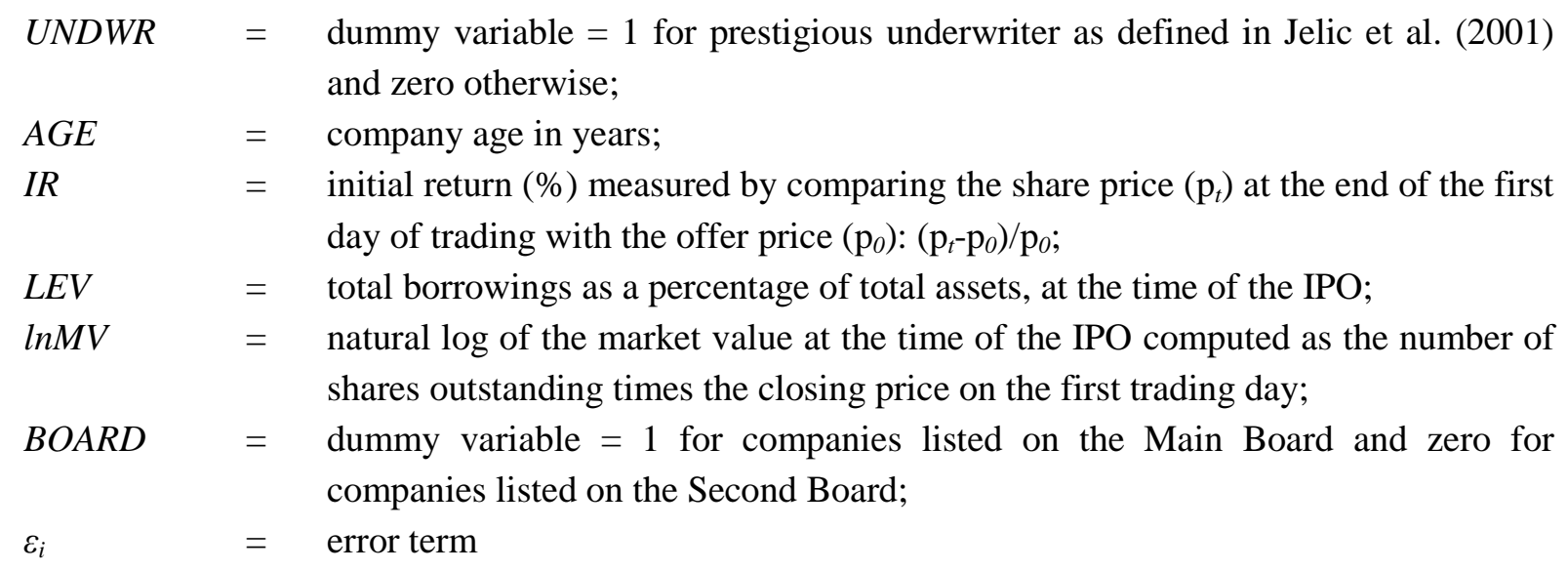

Significance levels are computed as White's t-statistics to correct for heteroscedasticity.

\subsection{Measure of long run stock market performance}

In Malaysia, companies are required to issue their annual audited financial statements within four months of the close of their financial year. Thus, accruals from the accounting year ending immediately after the IPO are related to the stock market performance over a three year period, starting from four months after the financial year end up to 40 months after the IPO. Although Teoh et al. (1998a) observe that the appropriate benchmark for long run stock market performance is 'much debated in the asset pricing literature', their choice of benchmark did not affect the empirical link between earnings management and subsequent stock market returns. In the absence of a dominant method, and consistent with the greater investor-relevance argument advanced by Teoh et al. (1998a), compounded buy-and-hold returns, based on two benchmarks, are used. The long run abnormal performance for each company is estimated as the difference between the raw buy-and-hold return of an IPO company and the benchmark return. The two benchmarks employed are: (i) the KL Composite Index (KLCI), to represent a market benchmark; and (ii) a matched company. Barber and Lyon (1996) found that statistical tests of abnormal performance are well-specified only when sample companies are matched against control companies with similar pre-event performance. Consequently, a matched company is identified by industry, pre-IPO operating performance based on Operating Income/Sales (to control for the mean reversion tendencies in operating performance) and pre-IPO 
total assets (to control for size effects). ${ }^{5}$ To allow for the increase in size of many IPO companies that follows the issue of new shares in the IPO, the match is made with the closest, larger, non-IPO company. Median benchmark-adjusted buy-and-hold returns are reported across all IPO sample years and separately for the East Asian crisis and non-crisis periods. Following Teoh et al. (1998a) and others, comparison is made between sub-samples of IPO companies that engage in 'aggressive' (income-increasing top quartile DCA) and 'conservative' (income-reducing bottom quartile DCA) earnings management practices.

\section{Sample selection and data}

The initial sample consists of 543 new companies listed on the Kuala Lumpur Stock Exchange during the period 1990 to 2000. Curtailing the test period at 2000 enables analysis of post-IPO long term performance. Thirty-nine companies classified as Infrastructure Project Companies, or included in the Finance, Trust and Closed-End Funds sectors, and five companies listed via the 'introduction' method, are excluded. ${ }^{6}$ One company that made a combination offering of debt and equity is also excluded to avoid any confounding effects of the debt issue. Also excluded are 151 companies without 'prior year' comparative figures in the first post-IPO published annual reports (such data are needed to estimate earnings management), 65 companies missing annual report files, 21 companies with incomplete five years of financial data and 7 companies that changed financial year end. Finally, four companies with extreme discretionary accruals are excluded to avoid undue influence by outliers. The final sample is 250 IPO companies with 97 in the 'Basic Industries' sector, 57 in 'Consumer

\footnotetext{
${ }^{5}$ The matched company is required to have pre-IPO (year -1) operating income/sales within the range of 90\% to $110 \%$ of the sample IPO company operating income/sales and beginning total assets within $70 \%$ to $130 \%$ of sample IPO company total assets in year -1 . Similar filter levels are applied by Barber and Lyon (1996) while Teoh et al. (1998) use operating income/sales for performance matching. Of the 250 sample IPO companies, 36 are matched on the basis of industry, pre-IPO performance, and total assets, 136 on industry and pre-IPO performance and 68 on industry only. Of the remaining 10 companies, four are matched on pre-IPO performance and total assets and six are matched only on pre-IPO performance regardless of industry. Application of the comprehensive three measure matching process is limited by the small number of Malaysian listed companies in some industries.

${ }^{6}$ We exclude Infrastructure Project Companies since they have special listing regulations (e.g., no minimum profit track record or market capitalisation requirement). We also exclude the Finance, Trust and Closed-End Fund sector given their different characteristics, but the Properties (Real Estate) sector was included as it is not classified as a financial sector by the Kuala Lumpur Stock Exchange.
} 
Goods', 39 in 'General Industrial and IT', 34 in 'Services', 17 in 'Real Estate Development' and 6 in 'Resources and Utilities’.

Stock returns and financial data are from Datastream, the Pacific-Basin Capital Market (PACAP) Research Centre database, and annual reports. The accrual variables to measure DCA during the IPO year (year 0) are hand-collected from the first post-IPO published annual reports, which included the financial information for both pre- and post-IPO years. Consistent with Teoh et al. (1998a), the first published annual reports after the IPO are used due to incomplete data in the prospectus financial statements.

\section{Results}

\subsection{Descriptive statistics}

Table 1 presents descriptive statistics for the full sample of 250 Malaysian IPOs and separately for Main Board (91 IPOs) and Second Board (159 IPOs) listings. ${ }^{7}$ Market value, sales and total assets data are in constant 2002 Malaysian Ringgits (RM), adjusted using the Malaysian Consumer Price Index. Mean (median) market value for the full sample is RM552 million (RM182 million), which is equivalent to approximately £90 million, or \$US145 million based on 2002 exchange rates. IPO companies listed on the Main Board are typically much larger (mean market value $=$ RM1,257 million) than those listed on the Second Board (RM148 million). Even so, as can be seen from the market value range, some relatively large IPOs are listed on the Second Board. Main Board companies are also significantly larger based on alternative size proxies (sales and total assets) but they have lower leverage. Operating performance prior to the IPO, measured by operating income

\footnotetext{
${ }^{7}$ Our study does not differentiate between private IPOs and privatisation IPOs (PIPOs), i.e., IPOs in which stateowned enterprises are listed on a stock market to achieve partial or full private ownership. The number of PIPOs is small (15 companies out of 250) and when PIPOs were excluded the results were almost identical. AhmadZaluki et al. (2007) also found no significant difference in performance between private IPOs and PIPOs.
} 
deflated by sales (OI/Sales), is also better for Main Board companies (median $=16.3 \%$ compared to $13.6 \%)^{8}$

The average age of Malaysian IPO companies is 11 years, slightly higher than the 9 years for US companies (Teoh et al., 1998), but considerably lower than the 35 years for Dutch companies (Roosenboom et al., 2003). Main Board companies have a longer operating history than Second Board companies. The mean (median) level of initial return, or underpricing, is $100 \%$ (86\%), higher than in many other countries but almost identical to recent findings for Malaysia (e.g., Jelic et al., 2001; How et al., 2007). The mean proportionate ownership retained by the original owners (retained ownership) is $77 \%$, which is broadly similar to other countries (e.g., US: 71\%, Jain \& Kini, 1994; UK: 74\%, Keasey \& Short, 1997) but higher than some (e.g., Thailand: 39\%, Kim et al., 2004; Australia: 51\%, Balatbat et al., 2004; US: 55\%, Albring et al., 2007). Significantly, the minimum retained ownership is marginally greater than $50 \%$, indicating that owners retained majority control in all of the sample companies following the IPO issue. Control retention appears to be an important dimension of the IPO market in Malaysia. The levels of initial return and retained ownership are similar across Main and Second Board companies. Over half of the IPO companies (56\%) choose Big 5 auditors and the same percentage choose prestigious underwriters but, as expected, Main Board (larger) IPOs typically opt for higher quality advisers.

[Insert Table 1 about here]

\subsection{Earnings management and its time-series distribution}

The last row of Table 1 reports the IPO year level of discretionary current accruals as a percentage of lagged total assets (DCA). Consistent with most prior studies, median (mean) DCA is income-increasing, at $2.92 \%(3.78 \%)$ and statistically significant at the $1 \%$ level. Such evidence is consistent with hypothesis 1 . However, there is also a wide range of earnings management as indicated in the reported minimum and maximum DCA levels.

\footnotetext{
${ }^{8}$ Equivalent mean (median) statistics for matched companies used in one of the long-term return benchmarks are: OI/Sales 15.3\% (13.6\%); total assets RM1,604 (327) million; market value RM1,868 (467) million.
} 
Information asymmetry is likely lower in Main Board companies as they require more paid-up capital, a longer trading history, have greater prospectus requirements and are typically larger than those on the Second Board. Thus, Second Board IPO companies may be able to retain private information more successfully than larger companies, suggesting greater potential to engage in earnings management. Indeed, weak evidence of this exists, as companies listed on the Second Board demonstrate a higher level of year 0 income-increasing DCA (median $=4.04 \%$ ) than the Main Board (median $=1.47 \%$ ) but the difference is not statistically significant. This suggests that board listing per se is unlikely to be a major determinant of IPO year earnings management.

Distributions of IPO year DCA for each year in the sample period are presented in Table $2 .^{9}$ We find a wide variation across the years with statistically significant (income-increasing) DCA observed in just two of the 11 years. The level of income-increasing earnings management is much higher in 1997 and 1998 (significant at the 1\% and 5\% levels, respectively), which differs from the other years (Kruskal-Wallis test, $p$-value $=0.039$ ). Of the nine years with insignificant DCA, the median is negative in 4 years and is positive but less than $1 \%$ in two years. Overall, $61 \%$ of the 250 IPOs have income-increasing DCA (row 4), significantly greater than the $50 \%$ expected by chance, but this is mainly driven by 1997 and 1998. These observations suggest that 'opportunistic' incomeincreasing earnings management is not pervasive in the Malaysian market.

Similarly, we find no evidence of substantial income-reducing earnings management. Only two years in the period $(1991,1999)$ have more than a random $(50 \%)$ proportion of IPOs with incomereducing DCA, and then only marginally (non-significant). The factors argued to encourage such behavior in non-IPO situations (such as price controls and company distress) are absent during most of the period, and are also less likely to affect companies deemed suitable to go to the market to raise additional finance via an IPO. This evidence suggests that pre-IPO owners in Malaysia do not typically use accruals to depress earnings to ensure underpricing for signaling purposes.

\footnotetext{
${ }^{9}$ Table 2 also suggests that 1996 and 1997, with larger numbers of IPOs, might be considered 'hot' IPO markets. However, there is no reason to believe that this will affect the analysis in later sections. Helwege and Liang (2004) find little evidence of different characteristics (such as company quality or operating performance) and no difference in the use of discretionary accruals between hot and cold market IPOs.
} 
[Insert Table 2 about here]

The two years with evidence of significant income-increasing earnings management (1997 and 1998) reflect the coincidence of two features of the Malaysian environmental: the East Asian crisis and the requirement for many companies to provide IPO profit guarantees. During the crisis years, investors are likely more selective when investing in IPOs which potentially encouraged incomeincreasing earnings management by company managers. Pressure to meet profit guarantees may also increase earnings management incentives. The high level of income-increasing DCA during 1997 and 1998 is consistent with such motivations. These patterns of earnings management are explored in greater detail below.

The last row of Table 2 identifies the numbers of sample IPOs each year during 1990-2000. Notice that the number of IPOs does not decline significantly during 1997, the first year of the East Asian crisis, though the number does fall sharply after 1997. The time distribution of sample IPOs reflects the overall pattern of 'population' IPOs which shows that there were 88 newly listed companies in 1997, just short of the peak of 92 companies in 1996. The high number of IPOs in 1997 is contrary to the expectation that fewer companies, perhaps only the desperate ones, choose to go public during a crisis. Given the likely downward pressure on offer prices, the high number of IPOs suggests motives other than short-term wealth maximization for going public during the crisis.

\subsection{Univariate analysis}

Univariate analysis is undertaken to: investigate patterns of DCA in years subsequent to the IPO; compare DCA in the East Asian crisis years (1997-1998) ${ }^{10}$ with non-crisis years; and, compare profit-guarantee with non-profit guarantee companies. These analyses are not tabulated but are summarized below.

\footnotetext{
${ }^{10}$ The East Asian crisis is usually considered to have started on 2 July 1997 with the floating (and prompt significant decline) of the Thai Baht, but there were large capital outflows from Malaysia earlier in 1997 combined with a decline in equity values from February onwards. Consequently, we treat all of 1997 as within the crisis period. The alternative of adopting July 1997 as the start of our 'crisis years' has no differential impact. There were 19 (24) IPOs in the first (last) 6 months of 1997, with median IPO year DCA of 10.3\% (9.4\%); i.e., IPOs were not all concentrated in the period prior to the official crisis start and the earnings management differences between first and last 6 months of 1997 are statistically insignificant.
} 
Overall (i.e., across all companies and all years), DCA are income-increasing and largest in the IPO year (year 0), with a median of $2.92 \%$ which declines to $1.33 \%$ in the year following the IPO (year +1 ), $1.20 \%$ (year +2 ) and $-0.65 \%$ (year +3 ); the first two (years 0 and +1 ) are statistically significant at $1 \%$ and $5 \%$ respectively. The level of IPO year (year 0 ) income-increasing earnings management is slightly lower than reported for the US (median $=5.5 \%$, Teoh et al., 1998; 4.0\%, Teoh et al., 1998a) and the Netherlands (3.9\%, Roosenboom et al., 2003). In the first year after the IPO (year +1 ), the median DCA of $1.33 \%$ remains income-increasing, which suggests that Malaysian IPO companies, on average, continue to manage their earnings upwards for the financial year immediately after the IPO. We see some evidence that accruals reverse 3 years beyond the IPO year. Similar results are reported for the US (reversal in year +2 , Teoh et al., 1998; in year +5 , Teoh et al.,1998a) but Roosenboom et al. (2003) report a significant DCA reversal to $-4.4 \%$ in year +1 in the Netherlands.

The unfavorable economic environment of the East Asian crisis may have caused some managers to engage in income-increasing earnings management to maintain investors' confidence. Analysis of the 57 IPOs in the crisis sub-period confirms that the level of earnings management is significantly income-increasing and is also significantly higher than for the 193 IPOs during non-crisis years. Separate columns in Table 2 show that IPO year DCA is income-increasing and large in the crisis years (median $=10.64 \%$, significant at the $1 \%$ level) but small and insignificant in the non-crisis years (median $=1.16 \%$ ); the difference between crisis and non-crisis DCA is statistically significant at the $1 \%$ level (two-tail). Of the IPOs during the crisis period, $75 \%$ exhibited income-increasing accruals compared with $57 \%$ in the non-crisis years (association statistically significant, at $5 \%$ level); a similar pattern was observed across both Main and Second Board companies. These observations support our hypotheses that income-increasing earnings management occurs during the 1997-1998 crisis period and at a higher level than during non-crisis periods (hypotheses 2 and 2a).

An important concern when interpreting this evidence is the extent to which selection bias explains the results. In other words, does the crisis (and profit guarantee requirement) influence the decision to take a company to market, leading to systematic differences in the characteristics of 
companies that issue an IPO during this period? Comparison with IPO companies in the non-crisis period reveals that those issuing IPOs during the crisis period were of similar size (MV, Sales), had similar operating performance in the pre-IPO year (OI/Sales) and similar leverage. This suggests that the IPO companies are financially strong, which is not surprising given the IPO success in the face of difficult market conditions.

Several IPO characteristics differ during the crisis period, however. We find a larger proportion of Second Board IPOs (79\% compared with 59\%), with a commensurately lower proportion of prestigious underwriters (43\%). Perhaps not unexpectedly, initial returns were lower (economically but not statistically significant) reflecting the tougher environment with less cash available for investment. Finally, retained ownership is statistically higher during the crisis period, with a mean (median) of $79.7 \%$ (84.7\%) compared to $75.7 \%$ (76.5\%). This increased retention is consistent with owners' recognition that an economic downturn is not the best time to seek cash for personal (or corporate) needs. The crisis period would encourage owners to minimise the impact on their long-term wealth by reducing the proportion of their holdings offered for sale at what they might consider to be 'depressed’ prices.

For part of the sample period (1995-1998) some Main Board and most Second Board IPOs were required to provide profit guarantees, which may affect the propensity to manage earnings. Unfortunately, the overlap between crisis and profit guarantee periods clouds the interpretation of results in a univariate framework. No sample Main Board companies provided guarantees ${ }^{11}$, but we can compare the earnings management of Second Board IPO companies that did provide a profit guarantee with those that did not. During the 1995-1998 profit guarantee period there were 83 Second Board IPOs. Analysis of these shows that profit guarantee companies exhibit income-increasing DCA, but only at significant levels during the crisis period (median DCA $=11.53 \%$ ). Importantly, we find no significant differences in earnings management between profit guarantee and non-profit guarantee companies (hypothesis 3 null cannot be rejected). Overall, the univariate results suggest that the East

\footnotetext{
${ }^{11}$ Prior to July 1997, the profit guarantee agreement was voluntary for certain Main Board Companies and for all Second Board companies but was then mandatory for all Second Board companies until March 1999.
} 
Asian crisis was a major factor in managers' decisions to manage IPO year earnings but motivations relating to the provision of profit guarantees were less important.

\subsection{Multivariate analysis}

Equation 1 was estimated to enable exploration of the hypotheses in a multivariate framework, while controlling for additional factors that may influence earnings management. As expected, there are moderate correlations between profit guarantee and crisis period (0.60), and between board of listing and company size (0.59). However, none of the other independent variables are highly correlated and variance inflation factors (VIF) are all less than 2, suggesting that multicollinearity is unlikely to be an issue.

Results for the OLS multivariate regression in Table 3 confirm the univariate analysis findings. Firstly, the crisis period is a major earnings management determinant $(t$-stat $=3.36)$, encouraging the use of income-increasing DCA perhaps to shore up profits to enable an IPO issue during the difficult economic climate. The coefficient for profit guarantee is negative but not statistically significant, confirming that the provision of a profit guarantee (PG) does not greatly affect the level of IPO earnings management. ${ }^{12}$

The percentage of retained ownership (RETOWN) has a significant positive relationship with earnings management; owners who retain a smaller (larger) proportion of their company post-IPO engage less (more) in income-increasing earnings management. ${ }^{13}$ This result contradicts the notion that owners maximize their short-term wealth by using income-increasing accruals to elevate the IPO offer price. Similarly, the positive relationship between retained ownership and DCA is inconsistent with a characterization where owners of high quality companies signal quality by underpricing shares sold at the IPO (potentially using income-reducing accruals). It is possible, however, that share

\footnotetext{
${ }^{12}$ In a separate regression based only on non-crisis years, PG remains negative but becomes marginally significant (10\% level), implying that companies that disclose profit guarantees have lower levels of incomeincreasing earnings management. Section 3.3 suggests several possible explanations for this.

${ }^{13}$ Separate regressions show this result to be consistent across both crisis and non-crisis years.
} 
moratorium (lock-up) regulations in Malaysia limit the incentives for signaling via owners' share retention.

The positive association between DCA and retained ownership is consistent with 'control concern’ incentives dominating such 'wealth protection' and signaling arguments. Hence, pre-IPO owners who sell a relatively large proportion of their ownership interest (low retained ownership) apparently forego the increase in immediate wealth that might accrue from a higher offer price as a result of income-increasing earnings management. They perhaps do so to ensure a high level of underpricing leading to oversubscription for the offer, thereby enabling shares to be allocated to many small investors. This reduces the threat of takeover and monitoring by large block holders (Brennan \& Franks, 1997), both of which are of greater concern to companies in which post-IPO retained ownership is relatively low. The result is consistent with Alavi et al. (2008) who find that managers are reluctant to allocate shares to large new shareholders when control retention is an important consideration.

Two control variables, AUDITOR and AGE, are also significant earnings management determinants. The significant negative coefficient on the proxy for auditors' reputation implies that companies audited by Big 5 auditors constrain (reduce) the level of income-increasing earnings management, consistent with prior IPO research in other countries (Zhou \& Elder, 2002; Chen et al., 2005). This suggests that either higher quality auditors are more likely to detect or deter earnings management, or managers of high quality IPOs, with reduced need to manage earnings, signal the quality by appointing high quality auditors. The significant negative coefficient on AGE suggests less uncertainty about the value of an IPO for a company with a longer operating history, thereby reducing the need and/or opportunity to use income-increasing DCA to manage earnings at the time of going public. Meanwhile, underwriter reputation (UNDWR), initial return (IR), leverage (LEV), company size $(\ln M V)$, and board of listing (BOARD) have no significant impact on earnings management. The insignificance of the initial return (underpricing) variable suggests that DCA are not related to first day returns, supporting the argument that earnings management is not generally undertaken for short-term wealth-related opportunistic reasons in Malaysia. 
[Insert Table 3 about here]

As a whole, these results support hypothesis 2a that income-increasing earnings management is higher in the crisis years. They provide little evidence that earnings management differs in profit guarantee companies (hypothesis 3). For hypothesis 4, there is strong evidence of a positive relationship between retained share ownership and income-increasing earnings management throughout the study period, consistent with the notion that concerns about post-IPO control may be more important than short-term wealth gains, or signaling, in the high ownership concentration Malaysian market. By contrast, Nagata and Hachiya (2006) find a negative relationship with retained ownership in the Japanese market, though the measures of owner interest differ.

Of the control variables, auditor reputation and company age are correlated with the level of earnings management but underwriter prestige, initial returns, leverage, company size and board of listing are not related to earnings management. ${ }^{14}$ Our results contrast with Aharony et al. (1993) who found that earnings management is more pronounced for smaller companies and for those with large financial leverage. Our results also differ from those of Wan-Hussin and Ripain (2003) who report that income smoothing is more prevalent among smaller companies.

\subsection{Earnings management and post-IPO stock market performance}

These results suggest income-increasing discretionary accruals, during the crisis period at least. Prior research evidence finds that IPO earnings management varies inversely with post-IPO performance. In light of this, the association between DCAs and post-IPO performance is also examined. This is of particular interest given our general lack of evidence in Malaysia of opportunistic earnings management behavior. To perform this analysis, the sample is first partitioned into quartiles based on the level of DCA across the study period and comparison is then made between 'high' and

\footnotetext{
${ }^{14}$ Given the moderate correlations between board of listing, company size and initial returns, regressions were also performed with the first two variables separately excluded. Similarly, to test the robustness of the models to the company size measure, regressions were carried out with the alternate proxy $\ln$ (total assets). While occasional minor variations in significance levels were observed, the overall results were not affected.
} 
'low' categories. The low DCA income-reducing ('conservative') ${ }^{15}$ group has DCA less than -5.9\%, and the high DCA income-increasing ('aggressive') group has DCA greater than $+13.9 \%$.

Table 4 reports the data on long run stock market performance, showing the median buy-andhold abnormal returns (BHARs) using a market benchmark and a matched company benchmark. Returns are calculated for a three year period, commencing at the beginning of the fifth month after the IPO year financial year end to allow for a reporting lag. Three year BHARs are reported for all years, and also separately for crisis and non-crisis years. The percentage of companies in the incomeincreasing high DCA group in the crisis years is $42 \%$ (24 of 57 companies), significantly higher (chisquare $=17.2 ; \mathrm{p}<1 \%$ ) than the $20 \%$ (39 of 193 companies) in the non-crisis years; i.e., high DCA income-increasing ('aggressive') earnings management occurs more often during the crisis period.

\section{[Insert Table 4 about here]}

Overall, IPO companies underperform the market benchmark, with a median three year BHAR of $-26.87 \%$ (significant at the 1\% level). The difference in median underperformance for IPOs issued during the crisis period (-32.21\%) and the non-crisis period (-26.69\%) is not statistically significant. For non-crisis period IPOs, there is little difference in post-IPO performance between high DCA income-increasing ('aggressive') and low DCA income-reducing ('conservative') companies. By contrast, for IPOs issued during the crisis period, high DCA companies significantly underperform low DCA companies with median three-year BHARs of $-42.77 \%$ and $+21.70 \%$, respectively (difference significant at the $5 \%$ level). The alternative benchmark of matched company returns shows a smaller, and insignificant, level of underperformance in the three-year holding period (median BHAR $=-5.77 \%)$. However, for the crisis period, high DCA income-increasing earnings management IPOs are again found to significantly underperform low DCA income-reducing earnings management companies. ${ }^{16}$

\footnotetext{
${ }^{15}$ The terms 'conservative' and 'aggressive' are used in the initial major US study of the link between earnings management and long-run post-IPO performance by Teoh et al., (1998a) and some later studies (e.g., PastorLlorca \& Poveda-Fuentes, 2006).

${ }^{16}$ Robustness checks using mean BHARs and also partitioning the sample into tertiles (rather than quartiles) based on the level of DCA produced similar results.
} 
Overall, there is strong evidence in support of hypothesis 5, which suggests that aggressive earnings management in IPO companies leads to long term underperformance, but only for IPOs issued during the period of economic crisis. No link exists between earnings management and long term performance during non-crisis periods. Studies using data from different countries find that IPO companies undertaking aggressive (income-increasing) earnings management underperform conservative earnings management IPO companies over a three-year holding period (Teoh et al., 1998a; Teoh et al., 1998; DuCharme et al., 2001; Roosenboom et al., 2003; Pastor-Llorca \& PovedaFuentes, 2006; Tykvová, 2006). ${ }^{17}$ By contrast, our results suggest that the relationship between earnings management and subsequent stock returns in Malaysia depends on the economic climate. Economic stress (i.e., during the crisis period) increases the likelihood and level of aggressive (income-increasing) earnings management and aggressive earning management companies significantly underperform conservative (income-reducing) companies over a three-year holding period. During normal economic conditions, earnings management is less likely and aggressive earnings management companies do not underperform. This finding suggests that environmental factors should be considered in IPO studies.

It is also interesting to note here the earlier observation of a positive association between income-increasing earnings management and retained ownership. This suggests that, while minority shareholders suffer as a result of this long run underperformance, the pre-IPO owners also suffer their (larger) proportionate share of this. Thus, their apparent concerns for maintaining post-IPO control come at a significant cost. The relatively high initial IPO returns suggest underpricing and short-term wealth loss, which is exacerbated by relatively poor long run returns. All of which begs the question, why would such owners wish to take their companies to the market during an economic crisis? Why would they not defer the IPO to better times? One conjecture is that wealthy individuals with ownership interests use IPO issues to bolster liquidity during the crisis. In doing so, they forego long run wealth to maintain short run consumption.

\footnotetext{
${ }^{17}$ This has typically been used as evidence that managers behave 'opportunistically' in managing earnings at the time of the IPO. However, a competing explanation might be that it relates to IPO differential risk characteristics (such as information risk) that are being rationally priced in the market (Easley et al., 2002). We are grateful to one of the referees for suggesting this.
} 


\section{Conclusion}

Analysis using a sample of 250 Malaysian IPOs over the period 1990-2003 indicates incomeincreasing earnings management in the IPO year. However, these overall results appear to be driven mainly by IPOs during 1997 and 1998, two years reflecting the coincidence of the East Asian crisis and a requirement for many companies to provide profit guarantees. Further detailed univariate analysis suggests that income-increasing earnings management is not a general phenomenon. Rather, it is determined primarily by a period of economic stress (the East Asian crisis) with incentives relating to the profit guarantee requirement of relatively little importance.

Multivariate analysis confirms the importance of the crisis period and also identifies the significant impact of the owners' continuing interest in the post-IPO company. A positive relationship between retained ownership and earnings management is consistent with owners having concerns about post-IPO control of the company, and does not suggest 'opportunistic' earnings management to protect owners' wealth or owners seeking to signal IPO quality. Older companies and those audited by a prestigious (i.e., Big 5) audit firm exhibit lower levels of income-increasing earnings management, consistent with arguments that high quality audits reduce opportunities for managers to manipulate earnings. As a whole, our results support the argument that 'opportunistic' IPO earnings management is less pervasive than prior research suggests (Ball and Shivakumar, 2008). Environmental and company-specific factors appear to significantly influence earnings management decisions. In particular, within the high ownership concentration market of Malaysia, control concerns exert a significant influence over IPO earnings management.

Post-IPO market-based performance depends on the benchmark adopted. IPO companies significantly underperform the market benchmark over the three year post-IPO period, but there is no significant difference in performance when a matched-company benchmark was used. The relationship between earnings management and post-IPO performance is contingent on environmental factors. For IPOs issued during non-crisis years, income-increasing IPO earnings management is less pronounced and post-IPO market-based performance is not associated with the level of IPO year earnings management. However for Asian crisis period IPOs, aggressive (income-increasing) earnings 
management IPO companies performed less well than their more conservative counterparts. Combining this evidence with that for the level of retained ownership suggests that owners' concern about personal liquidity during the crisis is a significant contributory factor in encouraging the use of income-increasing DCA to facilitate IPO issues during a difficult economic climate. 


\section{References}

Abdul Rahman, R., \& Wan Abdullah, W.R. (2005). The new issue puzzle in Malaysia: performance and earnings management. Journal of Financial Reporting and Accounting, 3, 91-110.

Aharony, J., Lin, C-J., \& Loeb, M.P. (1993). Initial public offerings, accounting choices, and earnings management. Contemporary Accounting Research, 10, 61-81.

Ahmad-Zaluki, N.A., Campbell, K., \& Goodacre, A. (2007). The long run share price performance of Malaysian initial public offerings (IPOs). Journal of Business Finance \& Accounting, 34, 78-110.

Ahmed, K., Godfrey, J.M., \& Saleh, N.M. (2008). Market perceptions of discretionary accruals by debt renegotiating firms during economic downturn. International Journal of Accounting, 43, 114138.

Alavi, A., Pham, P.K., \& Pham, T.M. (2008). Pre-IPO ownership structure and its impact on the IPO process. Journal of Banking \& Finance, 32, 2361-2375.

Albring, S.M., Elder, R.J, \& Zhou, J. (2007). IPO underpricing and audit quality differentiation within non-Big 5 firms. International Journal of Auditing, 11, 115-131.

Balatbat, M.C.A., Taylor, S.L., \& Walter, T.S. (2004). Corporate governance, insider ownership and operating performance of Australian initial public offerings. Accounting and Finance, 44, 299-328.

Ball, R., \& Shivakumar, L. (2008). Earnings quality at initial public offerings. Journal of Accounting and Economics, 45, 324-349.

Bank Negara Malaysia (2005). Monthly Statistical Bulletin, available at http://www.bnm.gov.my/.

Barber, B.M., \& Lyon, J.D. (1996). Detecting abnormal operating performance: the empirical power and specification of test statistics. Journal of Financial Economics, 41, 359-399.

Brau, J.C., \& Fawcett, S.E. (2006). Initial public offerings: An analysis of theory and practice. Journal of Finance, 61, 399-436.

Brennan, M.J., \& Franks, J. (1997). Underpricing, ownership and control in initial public offerings of equity securities in the UK. Journal of Financial Economics, 45, 391-413.

Chen, G., Firth, M., \& Krishnan, G. (2001). Earnings forecast errors in IPO prospectuses and their associations with initial stock returns. Journal of Multinational Financial Management, 11, 225-240.

Chen, K.Y., Lin, K-L., \& Zhou, J. (2005). Audit quality and earnings management for Taiwan IPO firms. Managerial Auditing Journal, 20, 86-104.

Chia, Y.M., Lapsley, I., \& Lee, H-W. (2007). Choice of auditors and earnings management during the Asian financial crisis. Managerial Auditing Journal, 22, 177-196.

Cormier, D., \& Martinez, I. (2006). The association between management earnings forecasts, earnings management, and stock market valuation: evidence from French IPOs. International Journal of Accounting, 41, 209-236.

Dechow, P.M., Sloan, R.G., \& Sweeney, A.P. (1995). Detecting earnings management. Accounting Review, 70, 193-225.

Downes, D.H., \& Heinkel, R. (1982). Signaling and the valuation of unseasoned new issues. Journal of Finance, 37, 1-10. 
DuCharme, L.L., Malatesta, P.H., \& Sefcik, S.E. (2001). Earnings management: IPO valuation and subsequent performance. Journal of Accounting, Auditing and Finance, 16, 369-396.

DuCharme, L.L., Malatesta, P.H., \& Sefcik, S.E. (2004). Earnings management, stock issues, and shareholder lawsuits. Journal of Financial Economics, 71, 27-49.

Easley, D., Hvidkjaer, S., \& O’Hara, M. (2002). Is information risk a determinant of asset returns?. Journal of Finance, 57, 2185-2221.

Espenlaub, S., \& Tonks, I. (1998). Post-IPO directors' sales and reissuing activity: an empirical test of IPO signalling models. Journal of Business Finance \& Accounting, 25, 1037-1079.

Han, J.C.Y., \& Wang, S-W. (1998). Political costs and earnings management of oil companies during the 1990 Persian Gulf crisis. Accounting Review, 73, 103-117.

Helwege, J., \& Liang, N. (2004). Initial public offerings in hot and cold markets. Journal of Financial and Quantitative Analysis, 39, 541-569.

How, J., Jelic, R., Saadouni, B., \& Verhoeven, P. (2007). Share allocation and the performance of the KLSE second board IPOs. Pacific-Basin Finance Journal, 15, 292-317.

Jaggi, B., \& Lee, P. (2002). Earnings management response to debt covenant violations and debt restructuring. Journal of Accounting, Auditing \& Finance, 17, 295-324.

Jain, B.A., \& Kini, O. (1994) The post-issue operating performance of IPO firms. Journal of Finance, 49, 1699-1726.

Jelic, R., Saadouni, B., \& Briston, R. (2001). Performance of Malaysian IPOs: underwriters reputation and management earnings forecasts. Pacific-Basin Finance Journal, 9, 457-486.

Jones, J.J. (1991). Earnings management during import relief investigations. Journal of Accounting Research, 29, 193-228.

Keasey, K., \& Short, H. (1997). Equity retention and initial public offerings: the influence of signalling and entrenchment effects. Applied Financial Economics, 7, 75-85.

Kim, K.A., Kitsabunnarat, P., \& Nofsinger, J.R. (2004). Ownership and operating performance in an emerging market: evidence from Thai IPO firms. Journal of Corporate Finance, 10, 355-381.

Kimbro, M.B. (2005). Managing underpricing? The case of pre-IPO discretionary accruals in China. Journal of International Financial Management and Accounting, 16, 231-262.

Leuz, C., Nanda, D., \& Wysocki P.D. (2003). Earnings management and investor protection: an international comparison. Journal of Financial Economics, 69, 505-527.

Lim, S., \& Matolcsy, Z. (1999). Earnings management of firms subject to product price controls. Accounting and Finance, 39, 131-150.

Nagata, K., \& Hachiya, T. (2006). Competing motives for earnings management in initial public offerings: to reduce wealth loss or to keep control of the firm. Working Paper, Tokyo Institute of Technology.

Neill, J.D., Porciau, S.G., \& Schaefer, T.F. (1995). Accounting method choice and IPO valuation. Accounting Horizons, 9, 68-80.

Pastor-Llorca, M.J., \& Poveda-Fuentes, F. (2006). Earnings management and the long-run performance of Spanish initial public offerings, in Gregoriou, G.N. (ed), Initial Public Offerings: An International Perspective, Butterworth-Heinemann, Oxford, 81-112. 
Peasnell, K.V., Pope P.F., \& Young, S. (2000). Detecting earnings management using cross-sectional abnormal accruals models. Accounting and Business Research, 30, 313-326.

Pham, K.P., Kalev, P.S., \& Steen, A.B. (2003). Underpricing, stock allocation, ownership structure and post-listing liquidity of newly listed firms. Journal of Banking and Finance, 27, 919-947.

Roosenboom, P., van der Goot, T., \& Mertens, G. (2003). Earnings management and initial public offerings: evidence from the Netherlands. International Journal of Accounting, 38, 243-266.

Saleh, N.M., \& Ahmed, K. (2005). Earnings management of distressed firms during debt renegotiation. Accounting and Business Research, 35, 69-86.

Smith, M., Kestel, J., \& Robinson, P. (2001). Economic recession, corporate distress and income increasing accounting policy choice. Accounting Forum, 25, 334-352.

Spiess, D.K., \& Pettway, R.H. (1997). The IPO and first seasoned equity sale: issue proceeds, owner/managers' wealth, and the underpricing signal. Journal of Banking \& Finance, 21, 967-988.

Teoh, S.H., Welch, I., \& Wong, T.J., (1998a). Earnings management and the long-run market performance of initial public offerings. Journal of Finance, 53, 1935-1974.

Teoh, S.H., Welch, I., \& Wong, T.J. (1998b). Earnings management and the underperformance of seasoned equity offerings. Journal of Financial Economics, 50, 63-99.

Teoh, S.H., Wong, T.J., \& Rao, G.T. (1998). Are accruals during initial public offerings opportunistic? Review of Accounting Studies, 3, 175-208.

Tykvová, T. (2006). IPOs and earnings management in Germany, in Gregoriou, G.N. (ed), Initial Public Offerings: An International Perspective, Butterworth-Heinemann, Oxford, 281-296.

Wan-Hussin, W.N., \& Ripain, N. (2003). IPO profit guarantees and income smoothing. Analisis, 10, 119137.

Zhou, J., \& Elder, R.J. (2002). Audit firm size, industry specialization and earnings management by initial public offering firms. Working Paper, Syracuse University, Syracuse, NY. 
Table 1

Descriptive statistics for 250 Malaysian IPOs between 1990 and 2000

\begin{tabular}{|c|c|c|c|c|c|c|c|c|c|c|c|c|c|c|}
\hline \multirow[b]{2}{*}{ IPO company characteristics } & \multicolumn{3}{|c|}{ Mean } & \multirow[b]{2}{*}{$\begin{array}{l}\text { t-stat } \\
\text { for diff }\end{array}$} & \multicolumn{4}{|c|}{ Median } & \multicolumn{3}{|c|}{ Minimum } & \multicolumn{3}{|c|}{ Maximum } \\
\hline & All & $\begin{array}{l}\text { Main } \\
\text { Board }\end{array}$ & $\begin{array}{l}\text { Second } \\
\text { Board }\end{array}$ & & All & $\begin{array}{l}\text { Main } \\
\text { Board }\end{array}$ & $\begin{array}{c}\text { Second } \\
\text { Board }\end{array}$ & $\begin{array}{c}\text { z-stat } \\
\text { for } \\
\text { diff } \\
\end{array}$ & All & $\begin{array}{l}\text { Main } \\
\text { Board }\end{array}$ & $\begin{array}{l}\text { Second } \\
\text { Board }\end{array}$ & All & $\begin{array}{l}\text { Main } \\
\text { Board }\end{array}$ & $\begin{array}{c}\text { Second } \\
\text { Board }\end{array}$ \\
\hline Market value (RM million) & 551.9 & $1,256.6$ & 148.5 & $2.32^{* *}$ & 181.9 & 366.5 & 119.1 & $9.77^{* * *}$ & 25.2 & 61.5 & 25.2 & 36,166 & 36,166 & 513 \\
\hline Sales (RM million) & 158.3 & 300.9 & 76.6 & $3.28^{* * *}$ & 78.6 & 135.1 & 57.7 & $6.98^{* * *}$ & 14.1 & 19.0 & 14.1 & 5,101 & 5,101 & 414 \\
\hline Total assets (RM million) & 286.2 & 650.8 & 77.6 & $2.21^{* *}$ & 84.8 & 166.9 & 59.6 & $9.77^{* * *}$ & 13.8 & 40.7 & 13.8 & 20,467 & 20,467 & 795 \\
\hline Leverage (\%) & 17.1 & 15.8 & 17.9 & -0.95 & 14.4 & 11.5 & 15.5 & $-2.04^{* *}$ & 0.0 & 0.0 & 0.0 & 93 & 93 & 59 \\
\hline Operating income/Sales (\%) & 16.3 & 19.0 & 14.8 & $2.82^{* * *}$ & 13.9 & 16.3 & 13.6 & $2.04^{* *}$ & -24.3 & 1.1 & -24.3 & 63 & 63 & 42 \\
\hline Age (Years) & 11.2 & 13.1 & 10.1 & $2.65^{* * *}$ & 10.5 & 12.9 & 8.8 & $2.78^{* * *}$ & 0.7 & 0.7 & 0.7 & 60 & 40 & 60 \\
\hline Initial return (\%) & 99.9 & 94.9 & 102.8 & -0.66 & 86.1 & 85.9 & 86.3 & 0.32 & -53.8 & -37.2 & -53.8 & 400 & 387 & 400 \\
\hline Retained ownership (\%) & 76.6 & 75.9 & 77.0 & -0.80 & 79.1 & 76.7 & 80.5 & -0.56 & 50.4 & 54.6 & 50.4 & 97 & 97 & 88 \\
\hline Auditor - Big 5 (\%) & 56.6 & 64.8 & 51.9 & $1.97^{*}$ & na & na & na & $\mathrm{Na}$ & na & na & na & na & na & na \\
\hline Underwriter - prestigious (\%) & 55.8 & 61.4 & 52.6 & 1.33 & na & na & na & $\mathrm{Na}$ & na & na & na & na & na & na \\
\hline DCA in IPO year (\%) & $3.78^{* * *}$ & $4.06^{*}$ & $3.62^{* *}$ & 0.16 & $2.92^{* * *}$ & $1.47^{* *}$ & $4.04^{* * *}$ & -0.16 & -62.0 & -51.1 & -62.0 & 76.4 & 72.9 & 76.4 \\
\hline
\end{tabular}

This table shows descriptive statistics for 250 IPOs except for leverage, auditor and underwriter which are for 242 IPOs due to missing prospectuses. Market value is the number of shares outstanding after the IPO times the closing price on the first trading day. Sales and total assets are measured at the end of the financial year prior to the IPO. Market value, sales and total assets are expressed in constant 2002 prices, adjusted using the Consumer Price Index (CPI). Leverage is the level of borrowings divided by total assets at the prospectus date. Operating income/Sales is for the financial year prior to the IPO. Age is the number of years between incorporation and the IPO date. Initial return is the percentage difference between the closing price on the first trading day and the offer price. Retained ownership, $\alpha$ is calculated as in Downes and Heinkel (1982): $\alpha=\left(N-N_{p}-N_{s}\right) / N$, where $\alpha$ is the proportionate ownership retained by the insiders (original owners); $N$ is the total number of shares outstanding after the initial offer; $N_{p}$ is the number of primary shares in the initial offer (public issue); and $N_{s}$ is the number of secondary shares offered by the insiders for resale (offer for sale). Auditor - Big 5 is the percentage of companies audited by one of the Big 5 auditors. Underwriter - prestigious is the percentage of companies which used a prestigious underwriter, as defined in Jelic et al. (2001). DCA in IPO year is discretionary current accruals for the year in which the IPO occurred as a \% of lagged total assets; discretionary current accruals are estimated using the 'Modified Jones' method.

${ }^{* * *},{ }^{* *}$ and ${ }^{*}$ denote significantly different from zero at the $0.01,0.05$ and 0.10 levels, respectively, using two-tailed tests. The differences between the mean and median of the Main Board (n $=$ 91) and the Second Board ( $\mathrm{n}=159)$ are based on the independent $t$-test and the Mann-Whitney U test, respectively. 
Table 2

Distribution of IPO year DCA (\% of lagged total assets) classified by year of listing

\begin{tabular}{|c|c|c|c|c|c|c|c|c|c|c|c|c|c|c|}
\hline & & & & & & Year & & & & & & Crisis & Non-crisis & \\
\hline & 1990 & 1991 & 1992 & 1993 & 1994 & 1995 & 1996 & 1997 & 1998 & 1999 & 2000 & years & years & Overall \\
\hline Median (\%) & -0.32 & -1.72 & 0.66 & 2.7 & 4.67 & -0.69 & 0.87 & $10.00^{* * *}$ & $18.35^{* *}$ & -5.35 & 3.58 & $10.64^{* * *}$ & 1.16 & $2.92^{* * *}$ \\
\hline Mean (\%) & -1.31 & -2.73 & -3.24 & 4.22 & 0.47 & -1.84 & $5.32^{*}$ & $9.78^{* * *}$ & $14.07^{* *}$ & -5.22 & 13.57 & $10.84^{* * *}$ & 1.70 & $3.78^{* * *}$ \\
\hline Standard deviation (\%) & 17.48 & 17.34 & 22.25 & 14.22 & 25.19 & 25.08 & 19.19 & 16.46 & 20.52 & 17.64 & 33 & 17.45 & 22.03 & 21.39 \\
\hline$\%$ with positive DCA & 50 & 44 & 53 & $72^{*}$ & 62 & 50 & 59 & $72^{* * *}$ & $86^{* *}$ & 45 & 69 & $75^{* * *}$ & $57^{*}$ & $61^{* * *}$ \\
\hline Number of companies & 16 & 16 & 19 & 18 & 29 & 22 & 46 & 43 & 14 & 11 & 16 & 57 & 193 & 250 \\
\hline
\end{tabular}

1. Kruskal Wallis test for the difference in medians across all years (Chi-Square $=19.06$, $\mathrm{p}$-value $=0.039$ ).

2. One-way ANOVA test for the differences in means across all years $(\mathrm{F}=1.96$, $\mathrm{p}$-value $=0.039)$.

3. Crisis years are 1997 and 1998 and all other years are non-crisis years. Differences between crisis and non-crisis years are significant for the median (0.01 level, Mann-Whitney U test), mean ( 0.01 level, $t$-test) and ' $\%$ with positive DCA' ( 0.05 level, chi-squared test).

4. ${ }^{* * * * * *}$, and ${ }^{*}$ denote significantly different from zero at the $0.01,0.05$ and 0.10 levels, respectively, using two-tailed tests. The Wilcoxon signed-ranks test is used for the medians, the $t$-test is used for means and the binomial test for whether the ' $\%$ with positive DCA' differs from $50 \%$. 
Table 3

Determinants of earnings management

\begin{tabular}{|c|c|c|c|}
\hline & $\begin{array}{c}\text { Expected } \\
\text { sign }\end{array}$ & coeff & t-stat \\
\hline \multicolumn{4}{|c|}{ Experimental variables } \\
\hline CRISIS & + & 10.893 & $3.36^{* * *}$ \\
\hline$P G$ & ? & -5.562 & -1.48 \\
\hline RETOWN & $?$ & 0.438 & $3.15^{* * *}$ \\
\hline \multicolumn{4}{|c|}{ Control variables } \\
\hline AUDITOR & - & -7.557 & $-2.84^{* * *}$ \\
\hline UNDWR & - & -1.773 & -0.68 \\
\hline$A G E$ & - & -0.261 & $-1.70^{*}$ \\
\hline$I R$ & - & 0.010 & 0.64 \\
\hline$L E V$ & ? & -0.122 & -1.37 \\
\hline $\ln M V$ & - & 2.379 & 1.45 \\
\hline$B O A R D$ & - & -0.384 & -0.10 \\
\hline constant & & -34.263 & $-2.82^{* * *}$ \\
\hline$n$ & & \multicolumn{2}{|c|}{242} \\
\hline Adj R-square & & \multicolumn{2}{|c|}{$10.3 \%$} \\
\hline $\mathrm{F}$ & & \multicolumn{2}{|c|}{$3.90^{* * *}$} \\
\hline
\end{tabular}

This table reports an OLS regression with the level of IPO year DCA (\% of lagged total assets) as the dependent variable. CRISIS is a dummy equal to 1 for crisis years and zero otherwise, $P G$ is a dummy equal to 1 for companies that provide a profit guarantee disclosure and zero otherwise, RETOWN is the percentage of shares retained by insiders after the IPO, AUDITOR is a dummy equal to 1 for 'reputable' auditors and zero otherwise, UNDWR is a dummy equal to 1 for 'prestigious' underwriters and zero otherwise, $A G E$ is the age of companies in years, $I R$ is the initial return, $L E V$ is total borrowings as a percentage of total assets at the time of the IPO, $\ln M V$ is the natural $\log$ of the market value computed as the number of shares outstanding times the closing price on the first trading day, and BOARD is a dummy equal to 1 for companies listed on the Main Board and zero otherwise.

*** ${ }^{* *}$, and ${ }^{*}$ denote significantly different from zero at the $0.01,0.05$ and 0.10 levels, respectively, using White-corrected two-tailed tests. 
Table 4

Median three-year equally-weighted buy-and-hold abnormal returns

\begin{tabular}{|c|c|c|c|c|c|c|c|c|c|c|}
\hline & \multicolumn{3}{|c|}{ All years } & \multicolumn{3}{|c|}{ Crisis years } & \multicolumn{3}{|c|}{ Non-crisis years } & \multirow{2}{*}{$\begin{array}{c}\text { All } \\
\\
\text { z-stat for } \\
\text { diff (crisis - } \\
\text { non-crisis) }\end{array}$} \\
\hline & All & $\begin{array}{c}\text { Low } \\
\text { DCA } \\
\text { (Income- } \\
\text { reducing) }\end{array}$ & $\begin{array}{c}\text { High } \\
\text { DCA } \\
\text { (Income- } \\
\text { increasing) }\end{array}$ & All & $\begin{array}{c}\text { Low } \\
\text { DCA } \\
\text { (Income- } \\
\text { reducing) }\end{array}$ & $\begin{array}{c}\text { High } \\
\text { DCA } \\
\text { (Income- } \\
\text { increasing) }\end{array}$ & All & $\begin{array}{c}\text { Low } \\
\text { DCA } \\
\text { (Income- } \\
\text { reducing) }\end{array}$ & $\begin{array}{c}\text { High } \\
\text { DCA } \\
\text { (Income- } \\
\text { increasing) }\end{array}$ & \\
\hline Median market adjusted return (\%) & $-26.87^{* * *}$ & -23.22 & $-34.59^{* * *}$ & $-32.21^{*}$ & 21.70 & $-42.77^{* * *}$ & $-26.69^{* * *}$ & $-23.88^{* *}$ & -33.10 & -1.05 \\
\hline z-stat for diff (high-low DCA) & \multicolumn{3}{|c|}{$-1.82^{*}$} & & \multicolumn{2}{|c|}{$-2.49^{* *}$} & \multicolumn{4}{|c|}{0.44} \\
\hline $\begin{array}{l}\text { Median matched company- } \\
\text { adjusted return (\%) }\end{array}$ & -5.77 & -1.65 & $-20.60^{* *}$ & -5.14 & $96.70^{*}$ & $-58.10^{* *}$ & -6.40 & -22.80 & -17.60 & 0.86 \\
\hline z-stat for diff (high-low DCA) & \multicolumn{3}{|c|}{-1.59} & & \multicolumn{2}{|c|}{$-2.91^{* * *}$} & \multicolumn{3}{|c|}{0.05} & \\
\hline Number of companies & 250 & 63 & 63 & 57 & 10 & 24 & 193 & 53 & 39 & \\
\hline
\end{tabular}

This table reports median three-year buy-and-hold abnormal returns for all years (1990-2000), crisis (1997 and 1998) and non-crisis years (excluding 1997 and 1998), split by DCA. Low DCA refers to 'conservative' (income-reducing) IPOs and high DCA to 'aggressive' (income-increasing) IPOs; low (high) DCA represents the lowest (highest) quartile of DCAs across all sample IPOs. The market-adjusted and matched company-adjusted returns are calculated as IPO company return minus the market (KL Composite Index) return, and matched company return, respectively. The difference in median return between non-crisis years and crisis years, and between high and low DCA groups is based on the Mann-Whitney U test.

${ }^{* * *}, * *$, and ${ }^{*}$ denote significantly different from zero at the $0.01,0.05$, and 0.10 levels, respectively, using two-tailed tests. 